Article

\title{
Synthesis of Tri- and Disubstituted Fluorenols and Derivatives Thereof Using Catalytic $[2+2+2]$ Cyclotrimerization
}

\author{
Ilaria Caivano ${ }^{1}$, Reinhard P. Kaiser ${ }^{1} \mathbb{D}$, Florian Schnurrer ${ }^{1,2}$, Jiři Mosinger ${ }^{3} \mathbb{D}$, Ivana Císařová ${ }^{3}$, \\ David Nečas ${ }^{1}$ (D) and Martin Kotora ${ }^{1, *(D)}$ \\ 1 Department of Organic Chemistry, Faculty of Science, Charles University, Albertov 6, 12843 Praha 2, \\ Czech Republic; caivanoi@natur.cuni.cz (I.C.); reinhardpeter.kaiser@gmail.com (R.P.K.); \\ fschnurrer@ice.mpg.de (F.S.); david.necas@natur.cuni.cz (D.N.) \\ 2 Friedrich-Schiller-Universität Jena, D-07743 Fürstengraben 1, Germany \\ 3 Department of Inorganic Chemistry, Faculty of Science, Charles University, Albertov 6, 12843 Praha 2, \\ Czech Republic; jiri.mosinger@natur.cuni.cz (J.M.); ivana.cisarova@natur.cuni.cz (I.C.) \\ * Correspondence: martin.kotora@natur.cuni.cz; Tel.: +420-221-951-058
}

Received: 6 October 2019; Accepted: 5 November 2019; Published: 9 November 2019

\begin{abstract}
A method for regioselective synthesis of 2,4-disubstituted and more highly substituted fluorenols using catalytic [2+2+2]cyclotrimerization of mono- and disubstituted diynes with terminal alkynes was explored. In the former case, the preferential formation of the 2,4-regioisomers was achieved in the presence of $\mathrm{Cp}^{*} \mathrm{Ru}(\operatorname{cod}) \mathrm{Cl}$, whereas $\mathrm{Rh}$-based catalysts tended to provide 3,4-regioisomers as the major products. The 2,4-disubstituted fluorenols were converted into the corresponding 9,9'-spirobifluorene derivatives and their structural and photophysical properties were evaluated.
\end{abstract}

Keywords: catalysis; cyclotrimerization; spirobifluorene; fluorescence; regioselectivity

\section{Introduction}

Fluorenes are polycyclic aromatic compounds consisting of two benzene moieties bridged by a methylene group. Compounds with the fluorene scaffold can be found in natural products (e.g., dendroflorin, gramniphenols, vitrofolals, etc.), and many of these substances have interesting biological properties [1]. The unique fluorene moiety, because of its electron donating properties and their large steric hindrance due to its bulkiness, was also used to design effective phosphine ligands for organometallic reactions like Buchwald-Hartwig, Sonogashira, and Suzuki coupling [2]. The use of the Fmoc (9-fluorenylmethyloxycarbonyl) protective group in Merrifield peptide synthesis should also be mentioned [3]. Compounds with the fluorene, and especially spirobifluorene scaffolds, are also of interest in material sciences [4,5]. For example, it was shown as early as 2002 that a spirobifluorene-cored oligoaryl compound could act as an emitter or a host for blue organic light-emitting devices in thin-layer films [6]. As another example, a study showed that appropriate positioning of the donor-acceptor and chromophoric groups onto the fluorenone backbone made it possible to manipulate fluorenones to emit light in from green to blue range of the visible spectrum [7]. Further, copolymers of fluorene with fullerenes have been considered an interesting material for collecting solar light and are therefore promising materials for polymer photovoltaics [8]. One should also not forget the work in the area of spirobifluorenes by Poriel and others, who have devoted much effort to synthesis and property elucidation of various spirobifluorenes and their 2- [9-12] and 4-substituted congeners [12-16]. For example, comparison of photophysical properties of phenyl and pyrimidyl substituted spirobifluorenes in the C2 and C4 positions provided several observations [12]. 
First, the substitution by a phenyl unit at the C4 position results in weaker modification of the highest occupied molecular orbital (HOMO) and lowest unoccupied molecular orbital (LUMO) levels compared to substitution at the $\mathrm{C} 2$ position. This could be attributed to the potential extension of conjugation length and hence a decrease of the HOMO-LUMO gap. Second, the substitution by the electro-deficient pyrimidyl substituent compared to the phenyl one leads to a significant lowering of the LUMO level. However, to the best of our knowledge, there has not been a report on the study of multi-substituted spirobifluorenes, e.g. 2,4-disubstituted ones.

The lack of data is related to the problem of a simple and fast synthesis of a series of such compounds. Although the maternal spirobifluorene was prepared by Gomberg et al. in 1930 [17], this issue has not been addressed to date. All of the previous work used classic synthetic approaches for preparation of 2- or 4-substituted spirobifluorenes based on cross-coupling reactions, such as the Suzuki-Miyaura reaction [18]. Hence, a different and simple approach must be devised.

From a general point of view, the synthesis of compounds possessing specifically decorated benzene rings is an important task of organic synthesis. The most straightforward method for preparation of such compounds is catalytic $[2+2+2]$ cyclotrimerization $[19,20]$ of appropriately substituted alkynes. Since fluorenes belong to the class of compounds possessing benzene rings, we envisioned that their specifically decorated congeners could be prepared using such a methodology. Since our first endeavors in this respect rendered the synthesis of 1,2,3,4-tetrasubstituted fluorenols (precursors for spirobifluorenes) using catalytic cyclotrimerization reactions of suitably substituted diynes with alkynes [21,22], we expected that the same methodology could be applied in this instance as well. With these facts in mind, we set the following goals. First, we aimed to develop a method for the selective synthesis of variously substituted fluorenols (precursor for the respective spirofluorenes) based on catalytic $[2+2+2]$ cyclotrimerization reaction. The main attention was focused on the scope of the selective preparation of 1,2,4- and 1,3,4-trisubstituted, and mainly 2,4-disubstituted fluorenols. Second, we aimed to assess effect of a catalyst on 1,2,4- and 1,3,4-, and 2,4- and 2,3-selectivity in the synthesis of the respective fluorenols. Third, we aimed to convert the fluorenols into the corresponding spirobifluorenes. The attention was mainly focused on the preparation of 2,4-disubtituted spirobifluorenes. Fourth, we aimed to evaluate substituent effect in 2,4-disubtituted fluorenols on photophysical properties of the spirobifluorenes.

\section{Results}

\subsection{Synthesis of 1,2,4- and 1,3,4-Trisubstituted Fluorenols}

It has been well-established that cyclotrimerization of monosubstituted diynes with terminal alkynes catalyzed by various Rh-catalysts favor the preferential formation of 1,2-isomers (ortho-isomers) [23] at the expense of 1,3-isomers (meta-isomers). However, the selectivity, i.e., 1,2- and 1,3-isomer ratios, can be controlled by the ligand environment around the central rhodium atom-at least to a certain level-as shown recently by us and others [24-34]. This is the result of the reaction mechanism, although the true nature of such regioselectivity has not yet been exactly comprehended. A somewhat more complicated situation may arise when substituted diynes are cyclotrimerized with terminal alkynes. Such a situation was encountered during our study on synthesis of fluorenes using Rh-catalyzed catalytic cyclotrimerization [21]. In this instance, we carried out the cyclotrimerization of diynol 1 with ferrocenylethyne under catalysis of Wilkinson's catalyst. The reaction provided mixture of 3 (ortho-isomer) and 3' (meta-isomers) in a 3:1 and 2.5:1 ratio, respectively (Scheme 1). 


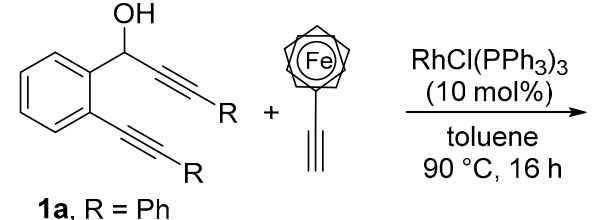

$1 \mathrm{~b}, \mathrm{R}=n-\mathrm{Pr}$

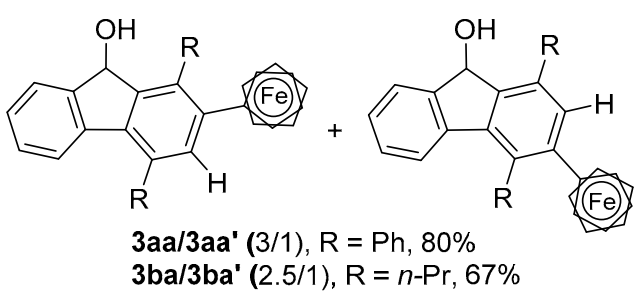

3ba/3ba' (2.5/1), $\mathrm{R}=n-\operatorname{Pr}, 67 \%$

Scheme 1. Cyclotrimerization of $\mathbf{1}$ with 2a catalyzed by Wilkinson catalyst.

In order to evaluate generality of this trend, i.e., 3 vs. $\mathbf{3}^{\prime}$ selectivity, a series of cyclotrimerizations of $1 \mathrm{c}$ with various terminal alkynes 2 was carried out (Table 1). During the course of the experiments, we found that carrying out the reaction under microwave irradiation and in the presence of $\mathrm{Ag}_{2} \mathrm{CO}_{3}$ gave better yields of the cylotrimerization products. After work-up, crude fluorenols were immediately oxidized to the corresponding fluorenones 4 with PCC, because they could be handled more easily than the maternal fluorenols 3 . In general, the isolated yields of mixtures of fluorenones 4 and $4^{\prime}$ may seem mediocre, but they reflected isolated yields after two steps and purification. Immediately, after running the cyclotrimerizations, crude reaction mixtures were analyzed by proton nuclear magnetic resonance ( ${ }^{1} \mathrm{H}$ NMR). The starting compounds 1 were consumed and fluorenols $\mathbf{3}$ were formed in approximately $50-60 \%$ yields (because of overlap of product signals with residual phopshine and other unidentified signals, exact determination was not possible). Another problem constituted separation of the products from residual phosphines, which was very problematic, tedious, and provided rather low isolated yields of the products. As far as potential homocyclotrimerization of $\mathbf{1}$ is concerned, the respective homotrimer was detected in yields of $2-7 \%\left({ }^{1} \mathrm{H}\right.$ NMR). In summary, the reactions with 4-methoxyphenylethyne $\mathbf{2 a}$, 4-methylphenylethyne $\mathbf{2} \mathbf{b}$, 3-thienylethyne $\mathbf{2 f}$, and trimethylsilylethyne 2h preferentially gave 1,3,4-regioisomer $4^{\prime}$ (Entries 1, 2, 6 and 8), whereas with 4-biphenylethyne 2c, phenylethyne $\mathbf{2 d}$, and 1-pentyne $\mathbf{2 g}$ preferentially provided 1,2,4-regioisomer 4 (Entries 3,4, and 7). Interestingly, the reaction with 4-trifluorophenylethyne $2 \mathrm{e}$ gave the equimolar mixture of 4 and $4^{\prime}$ (Entry 5). Concerning conclusions regarding the structural features of alkyne and the obtained regioisomer ratios, it was difficult to rationalize either on the basis of steric hindrance or electronic effects, e.g., polarization of the triple bond, at this point.

Table 1. Cyclotrimerization of 1c with 2 catalyzed by Wilkinson's catalyst.
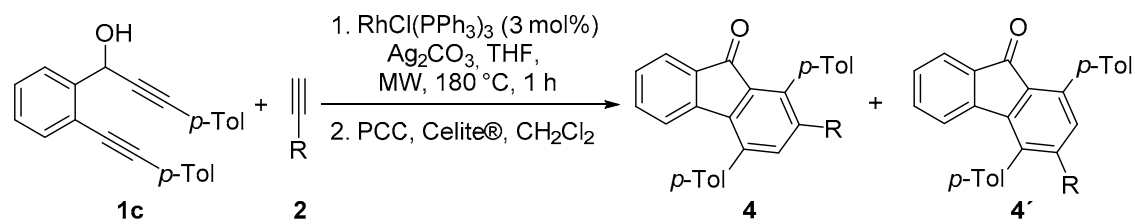

\begin{tabular}{ccccc}
\hline Entry & $\mathbf{R}$ & $\mathbf{2}$ & Yield (\%) $^{\mathbf{1}}$ & $\mathbf{4 : 4}^{\mathbf{2}^{\mathbf{2}}}$ \\
\hline 1 & $4-\mathrm{MeOC}_{6} \mathrm{H}_{4^{-}}$ & $\mathbf{2 a}$ & 43 & $1: 3.2$ \\
2 & $4-\mathrm{MeC}_{6} \mathrm{H}_{4^{-}}$ & $\mathbf{2 b}$ & 31 & $1: 1.6$ \\
3 & $4-\mathrm{PhC}_{6} \mathrm{H}_{4}{ }^{-}$ & $\mathbf{2 c}$ & 42 & $1: 0.7$ \\
4 & $\mathrm{Ph}^{-}$ & $\mathbf{2 d}$ & 23 & $1: 0.8$ \\
5 & $4-\mathrm{CF}_{3} \mathrm{C}_{6} \mathrm{H}_{4}{ }^{-}$ & $\mathbf{2 e}$ & 26 & $1: 1$ \\
6 & $3-$ thienyl & $\mathbf{2 f}$ & 18 & $1: 1.3$ \\
7 & $n-P r-$ & $\mathbf{2 g}$ & 25 & $1: 0.7$ \\
8 & $\mathrm{Me}_{3} \mathrm{Si}^{-}$ & $\mathbf{2 h}$ & 15 & $1: 2.4$ \\
\hline
\end{tabular}

${ }^{1}$ Isolated yields. ${ }^{2}$ Determined by proton nuclear magnetic resonance $\left({ }^{1} \mathrm{H}\right.$ NMR).

With respect to our previous work on ligand effect on regioselectivity [34], we were curious whether it was possible to control, or to alter, the regioisomer ratio by changing the ligand environment around the central metal atom. Namely, we asked whether it would be possible to shift the selectivity for formation of 1,2,4-trisubtituted fluorenols. In order to test ligand effect, a brief screening of four 
bidentate ligands, namely BINAP, dppp, dppb, and dppf, was undertaken [35,36]. As a model reaction the cyclotrimerization of diyne $\mathbf{1 c}$ with phenylacetylene $\mathbf{2 d}$ was chosen. The catalytic systems were formed by mixing of $\left[\mathrm{Rh}(\mathrm{cod})_{2}\right] \mathrm{BF}_{4}$ with an appropriate ligand at $60^{\circ} \mathrm{C}$ for $16 \mathrm{~h}$ (Table 2). In all cases, the full conversion of the starting material was observed. Because of the overlap of the phosphine signals with those of internal standards, ${ }^{1} \mathrm{H}$ NMR yields could not be determined accurately. However, a gross estimate of conversion to $4 \mathrm{~d}$ and $4 \mathrm{~d}^{\prime}$ was $\sim 40-50 \%$. The use of dppp and dppf had a positive effect on regioselectivity, preferentially giving rise to regioisomer $4 d^{\prime}$. The respective mixture of $4 d: 4 d^{\prime}$ were obtained in ratios of 1:3.2 and 1:2.4, respectively (Entries 1 and 5). Interestingly, the use of BINAPs provided mixtures containing a higher proportion of regioisomer $4 \mathbf{d}$ (Entries 3-4). The partial separation of $\mathbf{4} \mathbf{d}$ and $\mathbf{4} \mathbf{d}^{\prime}$ during column chromatography allowed isolation of a sufficient amount of $4 \mathrm{~d}^{\prime}$, which yielded a suitable material for single crystal X-ray diffraction analysis after recrystallization (Figure 1). The isolation and characterization of $4 \mathbf{d}$ and $4 \mathbf{d}^{\prime}$ allowed us to unequivocally interpret the recorded NMR data and determine the respective regioisomer ratios. Since it was next to impossible to separate other regioisomer mixtures into isomerically pure substances, the fluorenones were not converted into the corresponding spirobifluorenes.

Table 2. Cyclotrimerization of $1 \mathrm{c}$ with $\mathbf{2 d}$ catalyzed by Wilkinson's catalyst.

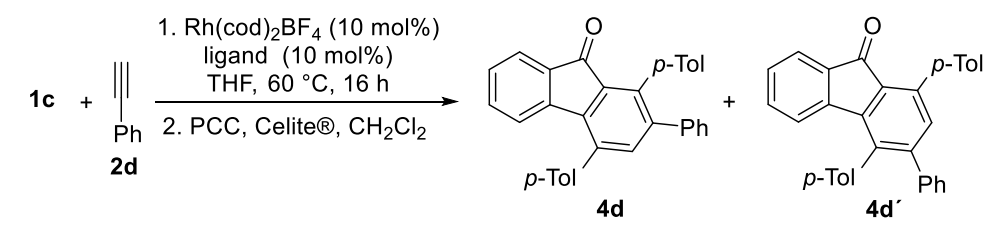

\begin{tabular}{|c|c|c|c|}
\hline Entry & Ligand & $\beta\left(^{\circ}\right)^{1}$ & $4 \mathrm{~d}: 4 \mathrm{~d}^{\prime 2}$ \\
\hline 1 & dppp & 91 & $1: 3.2$ \\
\hline 2 & $\mathrm{dppb}$ & 94 & $1: 1.6$ \\
\hline 3 & (R)-BINAP & 93 & $1: 0.7$ \\
\hline 4 & (S)-BINAP & 93 & $1: 0.8$ \\
\hline 5 & dppf & 99 & $1: 2.4$ \\
\hline
\end{tabular}

${ }^{1}$ Bite angle. ${ }^{2}$ Determined by ${ }^{1} \mathrm{H}$ NMR.

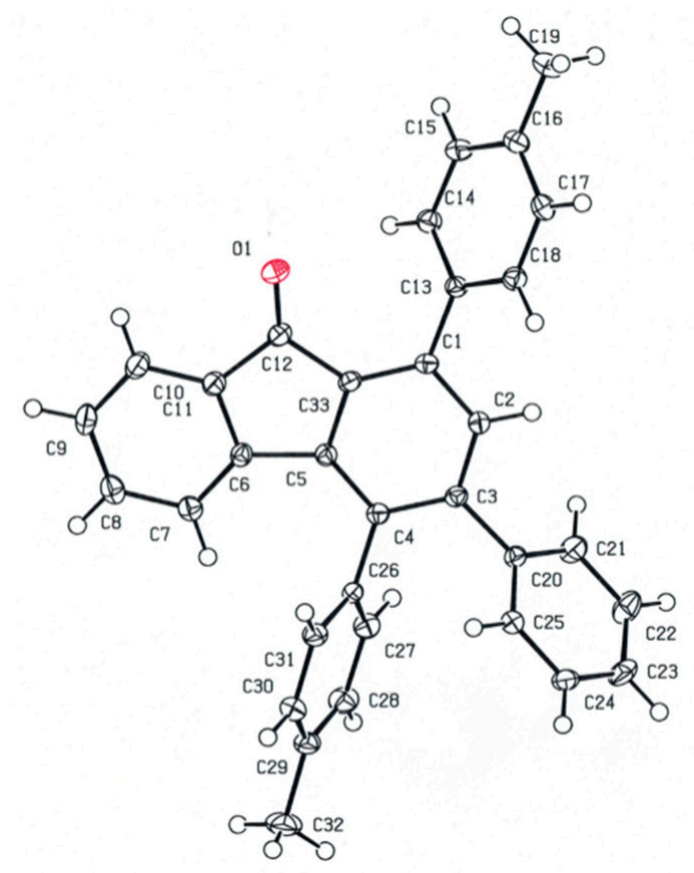

Figure 1. ORTEP drawing of $4 \mathbf{d}^{\prime}$ with $50 \%$ probability. 


\subsection{Synthesis of 2,4-Disubstituted Fluorenols}

In the next step, we focused on synthesis of disubstituted fluorenols with the main goal of synthesizing selectively 2,4-disubstituted fluorenols as precursors of the corresponding spirobifluorenes. Since only one example of a synthesis and application of a 2,4-disubstituted spirobifluorene has been reported [37] and there is a lack of data regarding their photophysical properties, we decided to develop a strategy for their preparation and to apply it for synthesis of a larger library of such compounds bearing aryl and other substituents with various electron-withdrawing or -donating substituents.

At the outset, we screened several catalytic systems to assess selectivity for the formation of 2,4-substituted fluorenols 6 (meta-isomer). A model reaction was chosen for the cyclotrimerization of diynol $\mathbf{5} \mathbf{a}$ with alkyne $\mathbf{2 b}$ (Table 3). As expected, the use of Wilkinson's catalyst (Entry 1) provided a preferential ortho-isomer $\mathbf{6 h}^{\prime}$. An attempt to modulate regioselectivity using the $\left[\mathrm{Rh}(\operatorname{cod})_{2}\right] \mathrm{BF}_{4} / \mathrm{dppp}$ system was not met with success, and $6 \mathrm{~h}^{\prime}$ was obtained as the major product (Entry 2). In the next step, we decided to use $\mathrm{Cp}^{*} \mathrm{Ru}(\mathrm{cod}) \mathrm{Cl}$, which is known to preferentially give rise to "meta-isomers". The preferential formation of the "meta-isomer" is the result of different reaction mechanism [38]. As expected, its use resulted in the preferential formation of $\mathbf{6 h}$ (a mixture of $\mathbf{6 h}$ and $\mathbf{6} \mathbf{h}^{\prime}$ was obtained in a 10:1 ratio) in a $46 \%$ combined isolated yield. A rather low yield of products was the consequence of undesirable homocyclotrimerization of 5 to 7 . In order to minimize the side reaction, cyclotrimerization of 5 a with various amounts of $\mathbf{2 b}$ (1-10 eq) were carried out (Table 4). However, when an excess of seven-fold or higher of $\mathbf{2} \mathbf{b}$ was used, the ratio remained almost constant at $\sim 5 / 1$ (Entries $5-7$ ).

With working reaction conditions in hand, we decided to proceed with synthesis of a library of 2,4-disubstituted fluorenols using Ru-catalysis (Scheme 2). All reactions were carried out with 5 and 2 (1:2 molar ratios) catalyzed by $\mathrm{Cp}^{*} \mathrm{Ru}(\mathrm{cod}) \mathrm{Cl}(10 \mathrm{~mol} \%)$ in dichloromethane at $20^{\circ} \mathrm{C}$ for $5 \mathrm{~h}$. The low molar ratio of 5:2 was kept for the sake of simplicity and to avoid high loads of alkynes 2 . The cyclotrimerization of 5 with various alkynes 2 provided a set of 15 differently substituted fluorenols 6a-6o. Thirteen cyclotrimerization were performed with $5 \mathbf{a}$ (fluorenols $\mathbf{6 a}-\mathbf{6 m}$ ) and two reactions were carried out with $\mathbf{5 b}$ (fluorenols $\mathbf{6 n}$ and $\mathbf{6 o}$ ). All products were obtained in isolated yields in the range of $14-62 \%$. Lower isolated yields of products reflected considerable homocyclotrimerization of $\mathbf{5}$ at the expense of the desirable cross-cyclotrimerization. Interestingly, regioisomer ratios of $\mathbf{6}$ and $\mathbf{6}^{\prime}$ varied from 3:1 to 25:1. There seemed to be a rough general trend, as phenylethynes bearing electron-withdrawing groups gave rather lower regioisomer ratios (e.g., 6a-6d), whereas those bearing electron-donating group gave higher ratios $(\mathbf{6 h}-\mathbf{6 k})$. Moreover, in some cases, it was possible to isolate the desired 2,4-disubstituted fluorenols $(\mathbf{6 a}-\mathbf{6 g}, \mathbf{6 k}, \mathbf{6 m}$, and $\mathbf{6 n})$, whereas, in other cases, the respective regioisomer mixtures were inseparable (6h-6j, and $\mathbf{6 1 , 6 0})$. As far as ${ }^{1} \mathrm{H} N \mathrm{NR}$ analysis of the regioisomer ratio was concerned, the "meta-regioisomers" were identified by the characteristic doublet in the range of 7.89-8.01 ppm $\left(J_{\text {meta }}=1.6 \mathrm{~Hz}\right)$. On the other hand, the "ortho-isomers" had characteristic doublets in the range of $6.22-6.45 \mathrm{ppm}\left(J_{\text {ortho }}=7.6 \mathrm{~Hz}\right)$. The ortho-isomer was isolated in the case of $\mathbf{6}^{\prime} \mathbf{n}$.

Table 3. Catalytic cyclotrimerization of $5 \mathbf{a}$ with $\mathbf{2 b}$ using different catalytic systems.

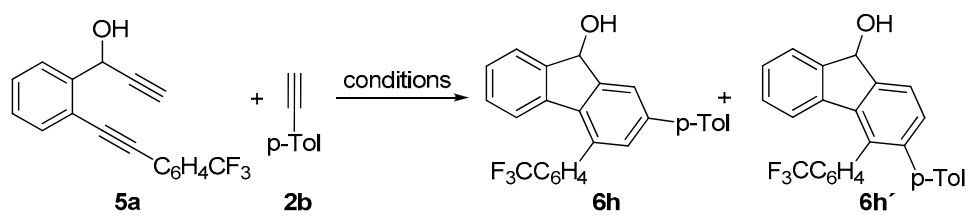

\begin{tabular}{ccccc}
\hline Entry & Catalytic system & Conditions & $\mathbf{6 h}^{\prime} \mathbf{6 \mathbf { h } ^ { \mathbf { 1 } }}$ & Yield (\%) $^{\mathbf{2}}$ \\
\hline 1 & {$\left[\mathrm{RhCl}\left(\mathrm{PPh}_{3}\right)_{3}\right](3 \mathrm{~mol} \%), \mathrm{Ag}_{2} \mathrm{CO}_{3}(6 \mathrm{~mol} \%)$} & $180^{\circ} \mathrm{C}, \mathrm{MW}, 1 \mathrm{~h}$ & $1: 2$ & 62 \\
2 & {$\left[\mathrm{Rh}(\mathrm{cod})_{2}\right] \mathrm{BF}_{4}(10 \mathrm{~mol} \%), \mathrm{dppp}$} & $\mathrm{THF}, 60{ }^{\circ} \mathrm{C}, 16 \mathrm{~h}$ & $1: 1.25$ & 40 \\
3 & $\mathrm{Cp} \mathrm{Ru}^{*}(\mathrm{cod}) \mathrm{Cl}(10 \mathrm{~mol} \%)$, & $\mathrm{CH}_{2} \mathrm{Cl}_{2}, 20^{\circ} \mathrm{C}, 5 \mathrm{~h}$ & $10: 1$ & 46 \\
\hline
\end{tabular}

${ }^{1}$ Determined by ${ }^{1} \mathrm{H}$ NMR. ${ }^{2}$ Combined isolated yields. 
Table 4. Catalytic cyclotrimerization of $\mathbf{5 a}$ with various amounts of $\mathbf{2 b}$.

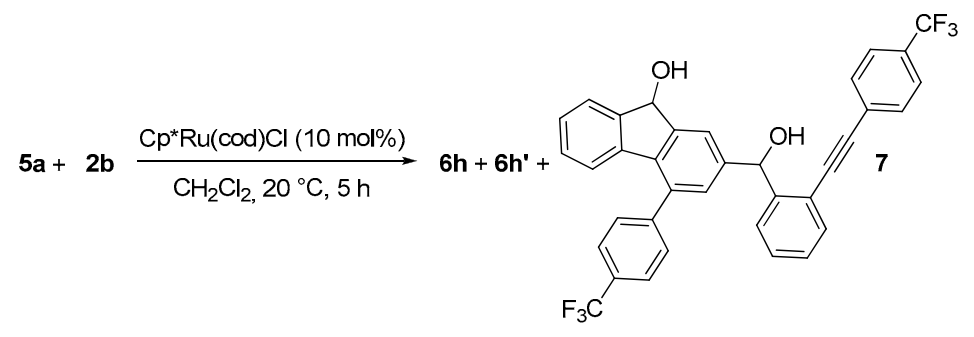

\begin{tabular}{|c|c|c|c|}
\hline Entry & $2 b(e q)$ & $6 h+6 h^{\prime}$, Yield $(\%)^{1}$ & 7 , Yield (\%) ${ }^{1}$ \\
\hline 1 & 2 & 46 & 40 \\
\hline 2 & 3 & 47 & 40 \\
\hline 3 & 4 & 66 & 19 \\
\hline 4 & 5 & 66 & 18 \\
\hline 5 & 7 & 75 & 14 \\
\hline 6 & 9 & 76 & 14 \\
\hline 7 & 10 & 77 & $15^{2}$ \\
\hline
\end{tabular}

${ }^{1}$ Isolated yields. ${ }^{21} \mathrm{H}$ NMR yields (1,2,4,5-tetramethylbenzene was used as the internal standard).

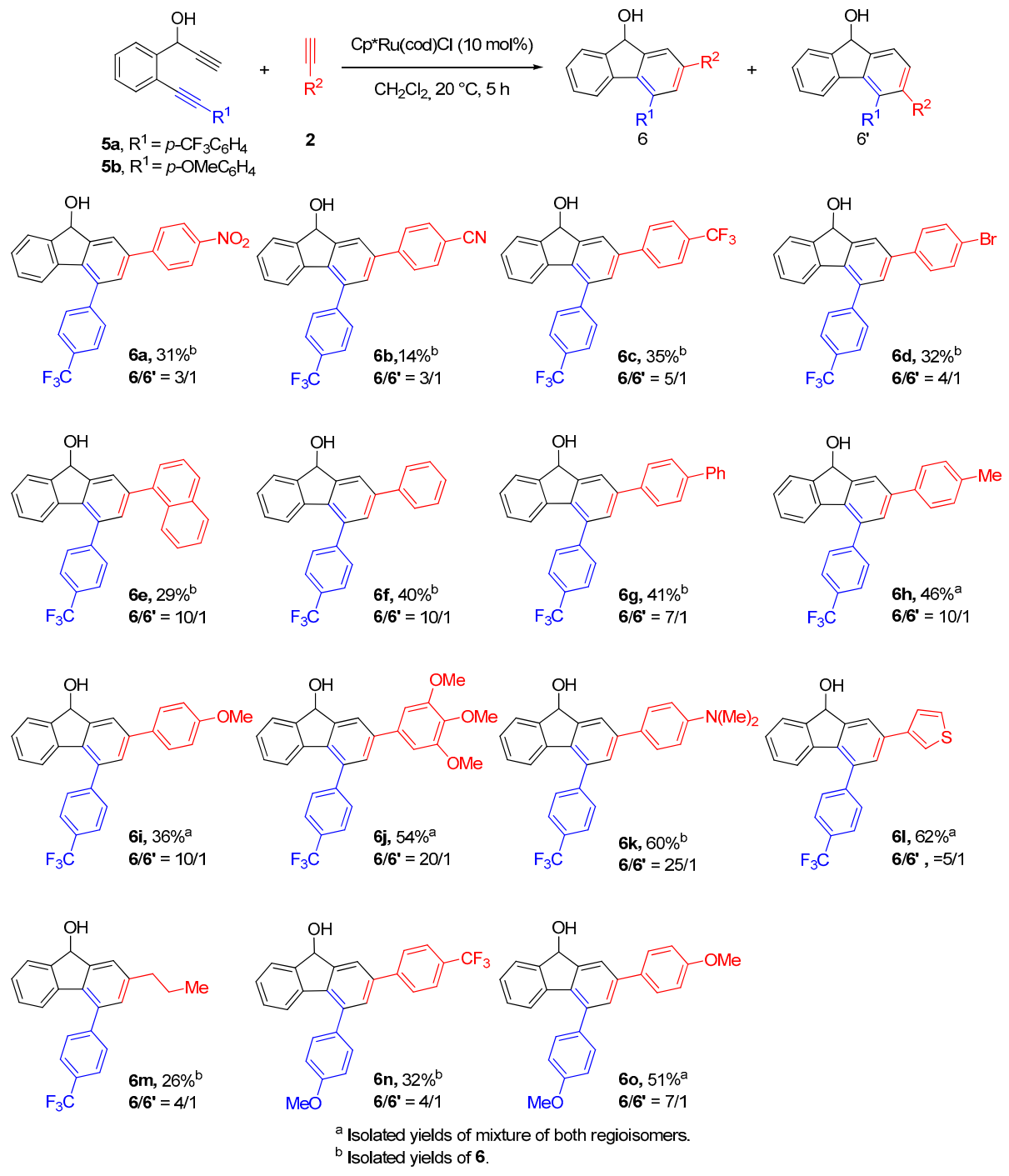

Scheme 2. Cyclotrimerization of 5 with 2 to 6 and $\mathbf{6}^{\prime}$. 
The fluorenols were converted in three steps to the corresponding spirobifluorenes 9 (Scheme 3) [17,39]. The first step involved the oxidations of 6 with PCC and proceeded uneventfully to yield the corresponding fluorenones 8 in generally high isolated yields (73-98\%). Their subsequent reactions with 2-biphenyllithium, followed by treatment with a mixture of $\mathrm{AcOH} / \mathrm{HCl}$ under reflux, resulted in good yields as well. In most cases, the corresponding spirobifluorenes 9 were obtained in a broad range of isolated yields (36-89\%). Again, in instances where lower isolated yields of 9 were obtained, considerable problems with purification were met, reducing the amount of obtained material. In two cases, the formation of spirobifluorenes was not successful. Conversion of $\mathbf{8 a}$ and $\mathbf{8 k}$ (obtained by oxidation of the respective fluorenols by $\mathrm{PCC}$ or $\mathrm{MnO}_{2}$, respectively) resulted in formation of complex reaction mixtures, in which the expected products were not detected.

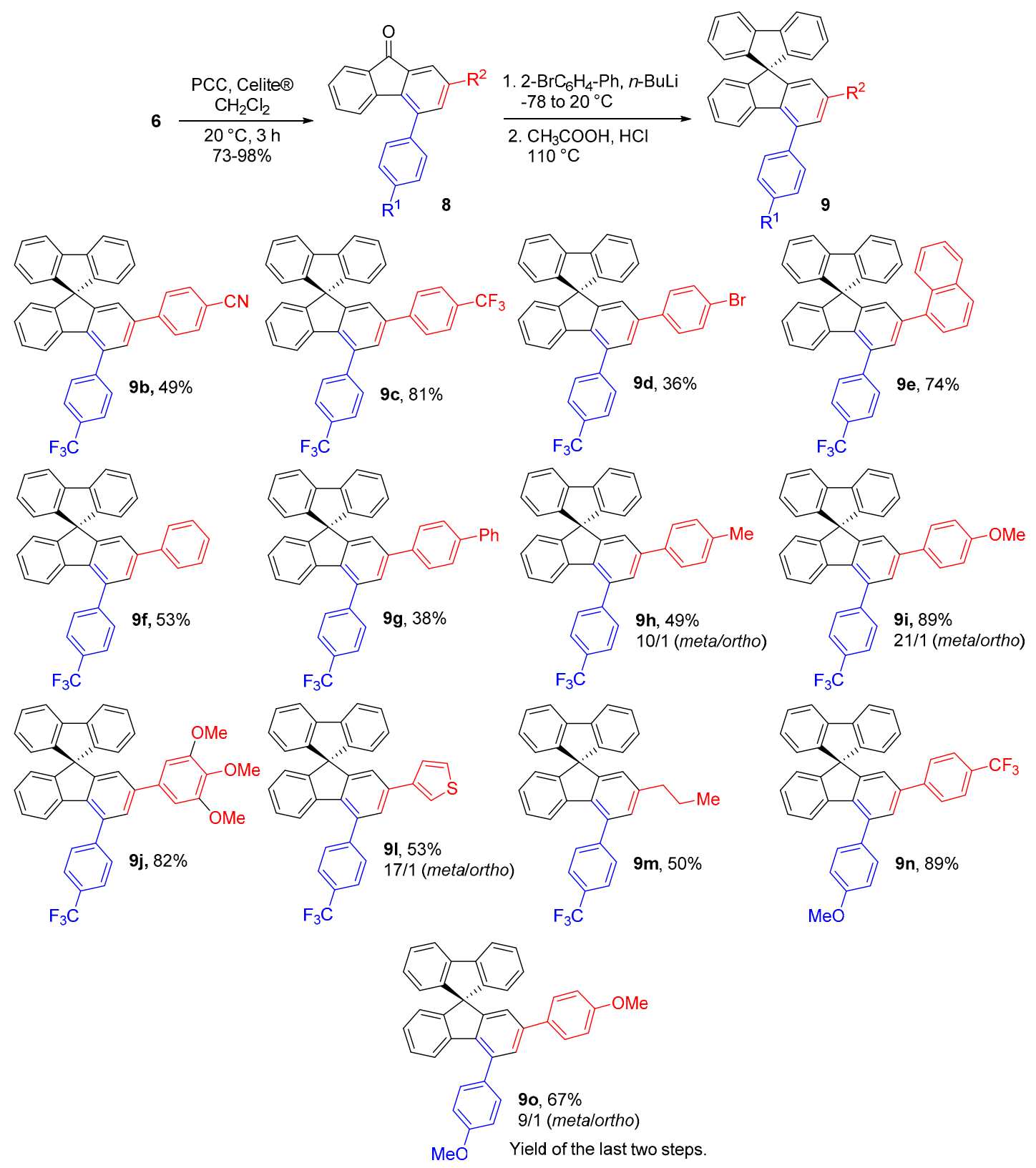

Scheme 3. Formation of spirobifluorenes 9. 


\subsection{Structural Analysis}

Attempts to crystalizes some of the spirobifluorenes were provided in case of $9 \mathrm{c}, 9 \mathrm{~g}, \mathbf{9 h}, \mathbf{9 \mathbf { h } ^ { \prime }}, \mathbf{9 i}$, and $\mathbf{9 n}$ suitable crystals for X-ray analysis. A typical example is displayed the structure of $\mathbf{9 g}$ (Figure 2).

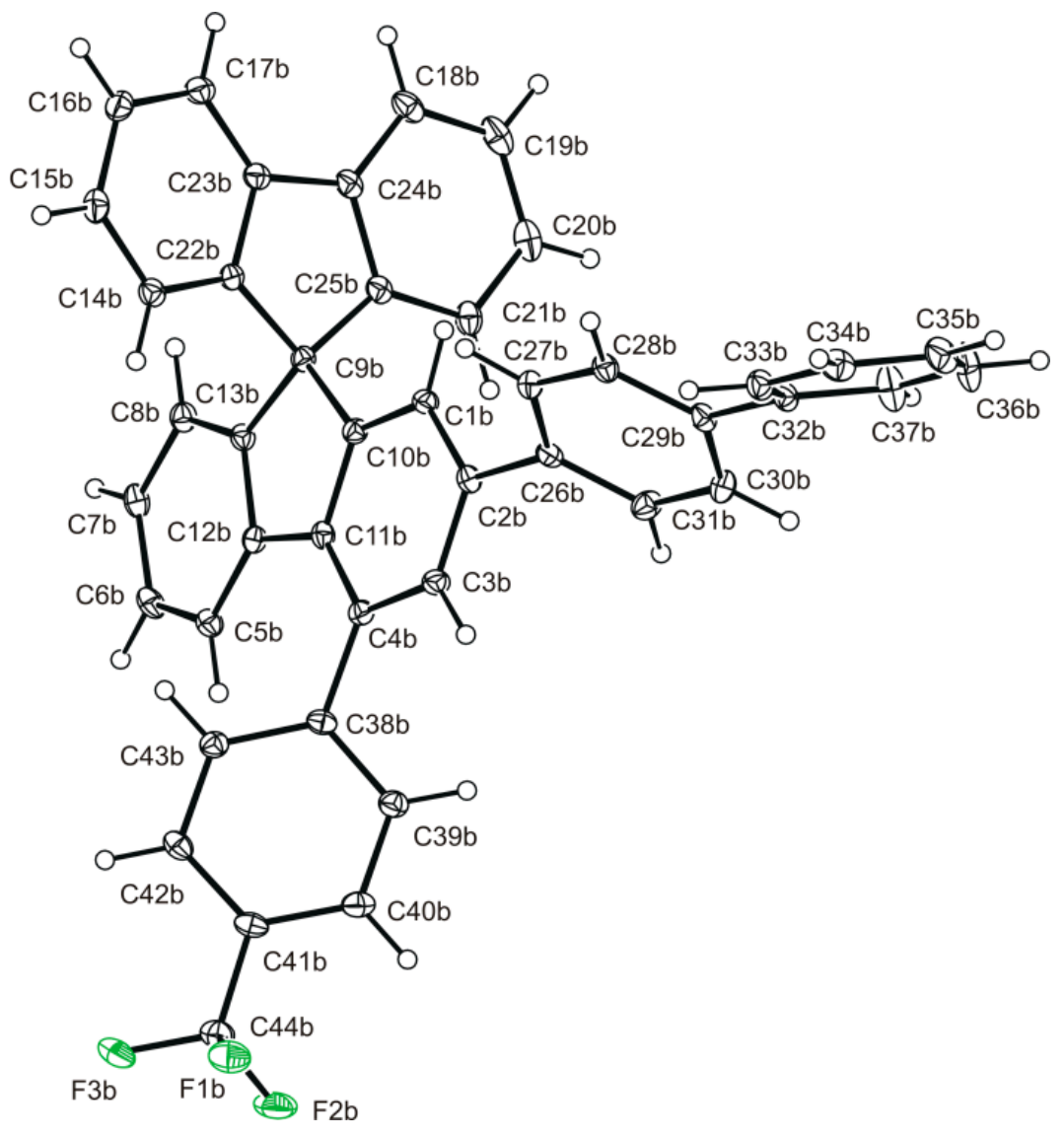

Figure 2. ORTEP drawing of $9 \mathrm{~g}$ with $50 \%$ probability.

In case of $9 c$, the structure determination was complicated by disorder of one $-\mathrm{CF}_{3}$, described by two positions of each fluorine atom with a ratio of occupancy factors of 0.62:0.38. The unit cell of $9 \mathrm{~g}$ contained two symmetrically independent molecules, from which one exhibited a disorder of $-\mathrm{CF}_{3}$ moiety, hampering the overall precision of results. In case of $9 \mathrm{~h}$, the $-\mathrm{CF}_{3}$ moieties were ordered. However, the position of one of the symmetrical molecules appeared to be occupied by two isomers with a ratio of $0.65: 0.35$. There were two symmetrically independent molecules in the unit cell of $9 \mathbf{h}^{\prime}$ with disordered $-\mathrm{CF}_{3}$ moieties. The most difficult structure from the whole series was that of $9 \mathbf{n}$. It was composed of six symmetrically independent molecules in the unit cell, which included one more disordered molecule than others, with overall large displacement parameters of most of the atoms. Therefore, the ability of the crystal to diffract was significantly low. The poor quality of the crystal was triggered on several alerts during validation. However, we decided to include this structure in the paper to complete the series of synthesized compounds.

Concerning the sum of the dihedral angle derived from three $\mathrm{C}-\mathrm{C}$ bonds (the inner rim C5-C12-C11-C4), which should reflect the degree of molecular twist, it took the following values: $8.1^{\circ}$ $\left(4 \mathrm{~d}^{\prime}\right), 1.8^{\circ}(9 \mathrm{c}), 7.9$ and $4.0^{\circ}(9 \mathrm{~g}), 2.8$ and $4.1^{\circ}(9 \mathrm{~h}), 2.1$ and $2.6\left(9 \mathrm{~h}^{\prime}\right), 1.3$ and $2.2(9 \mathbf{i})$, and $2.4-7.4^{\circ}(9 \mathrm{n})$. This indicates only a slight deformation of the fluorenyl core. 


\subsection{Photophysical Properties of Spirobifluorenes 9}

We investigated the photophysical properties of the prepared spirobifluorenes 9. All the 2,4-disubstituted spirobifluorenes exhibited a very similar absorption spectra (Figure 3) and presented two thin bands at $\sim 297$ and $\sim 309 \mathrm{~nm}$ (typical for all known unsubstituted and substituted SBFs) accompanied by a more or less intensive large band of lowest energy absorption centered in the range of 323-331 nm. This band was caused by the elongation of the $\pi$-electron system conjugation from the fluorene core to the phenyl ring of the substituents. At this low-energy wavelength, 2- $n$-Propyl-substituted $9 \mathrm{~m}$ presented just a low intensity tail and interpreted only a limited degree of conjugation between the SBF core and aromatic C4-substituent. Other SBFs bearing an aromatic substituent at position C2 were slightly more red-shifted and showed significantly larger bands corresponding to more effective conjugation.

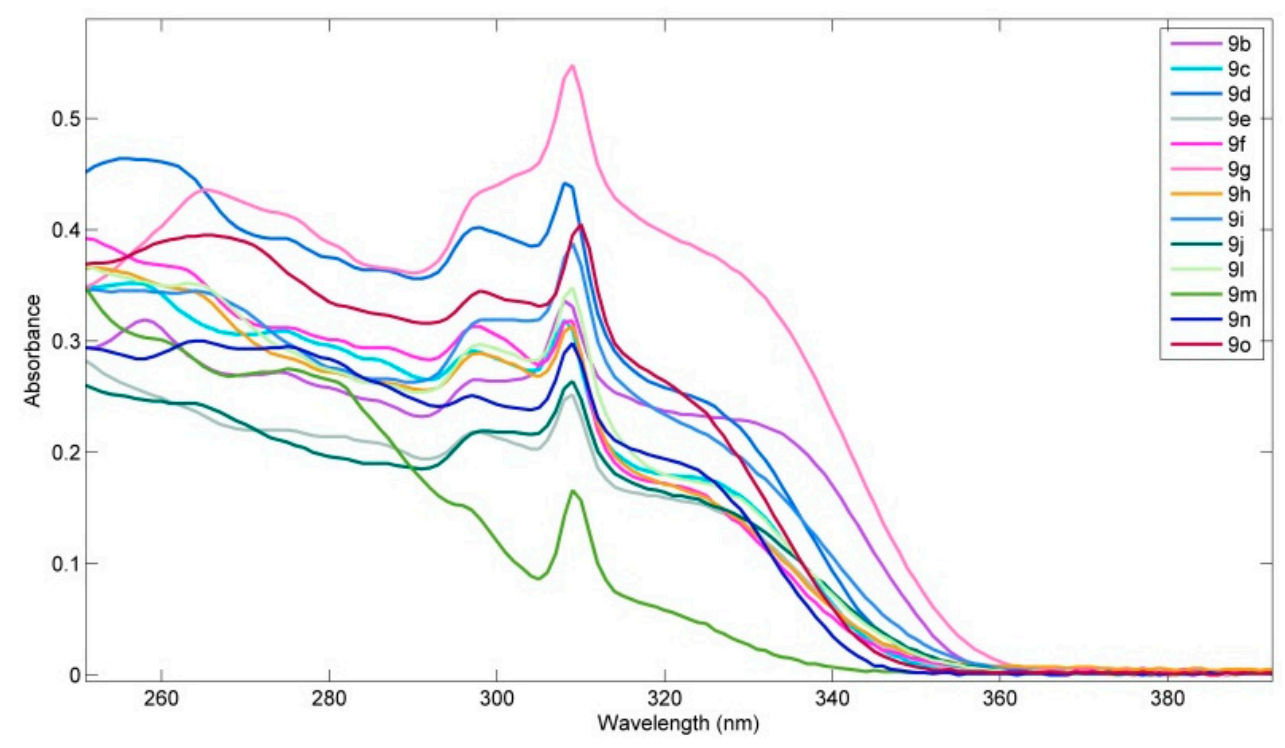

Figure 3. Absorption spectra of $\mathbf{9}\left(10^{-5} \mathrm{M}\right)$ in cyclohexane.

The fluorescence spectra of SBFs 9 recorded in cyclohexane are presented in Figure 4. All the emission spectra evinced unresolved $(\mathbf{9 b}, \mathbf{9 c}, \mathbf{9 i}, \mathbf{9 j}, \mathbf{9 n}$, and $\mathbf{9 0})$ or only partially resolved (9d-9h, 91, and 9m) character peculiar to other 4-aryl substituted SBFs [13,21,22,39-44]. The obtained emission maxima ranged from $365 \mathrm{~nm}$ to $391 \mathrm{~nm}$, whereas the emission spectra and maxima of C4-methoxyphenyl-substituted SBFs 9n and 9o were almost unnoticeably changed by the alteration of the C2 substituent (365 vs. $367 \mathrm{~nm}$, SI-Figure S10, see SI). The emission characteristics of C4-trifluoromethylphenyl-substituted SBFs $9 \mathbf{b}-9 \mathrm{~m}$ can be modulated by the electron density on C2-aryl substituent (e.g., 9c $369 \mathrm{~nm}$ vs,.9i $387 \mathrm{~nm}$ or $\mathbf{9 j} 391 \mathrm{~nm}$, SI-Figure S11, see SI). The Stokes shifts (up to $66 \mathrm{~nm}, \sim 5200 \mathrm{~cm}^{-1}$ ) and large and structureless emission fluorescence spectra of the prepared SBFs can be rationalized by high flexibility via the strong reorganization between geometries of $S_{0}$ (ground state) and $S_{1}$ (first singlet excited state), which were typical for the majority of the C4-aryl-substituted SBFs [45]. The absolute quantum yields $\left(\Phi_{\mathrm{s}}\right)$ were determined in cyclohexane and were in the range of $\Phi_{\mathrm{s}}=0.14-1$ (Table 5). Thus, with the exception of a few, the SBFs 9 represented efficient UVA emitters. 


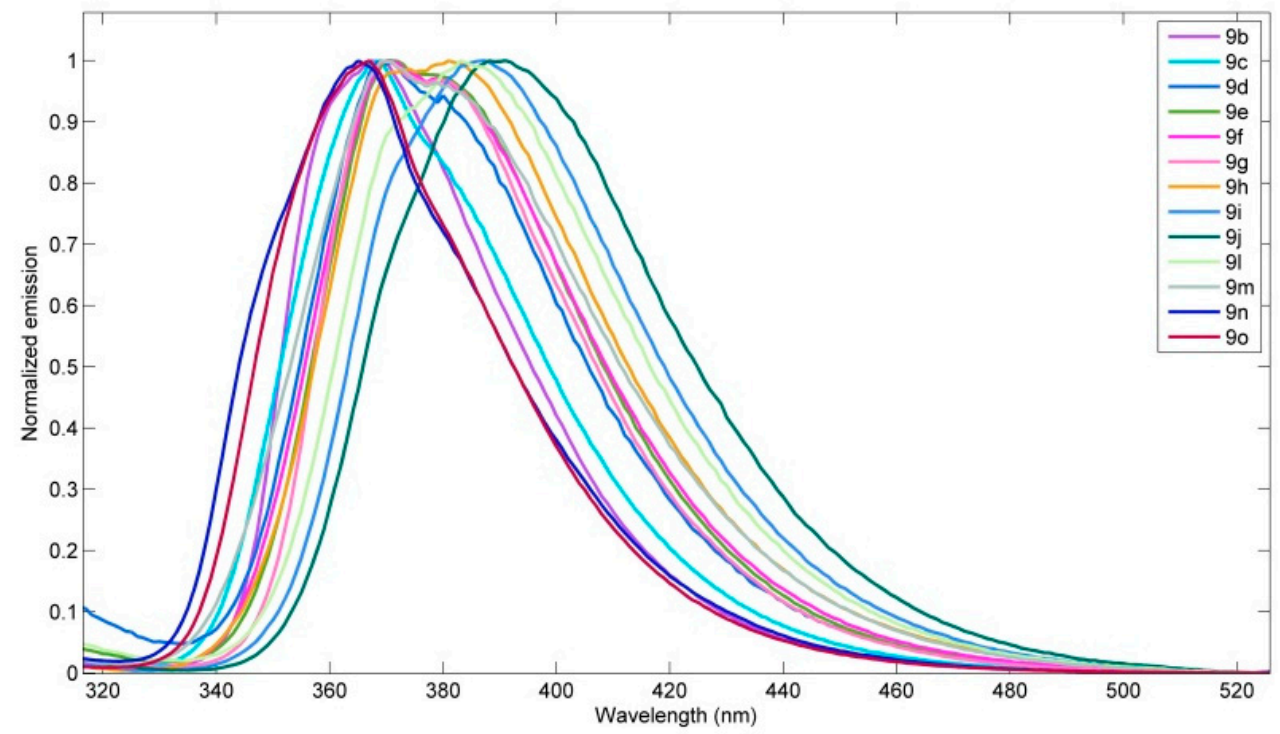

Figure 4. Normalized emission spectra of $9\left(10^{-6} \mathrm{M}\right)$ in cyclohexane.

Table 5. Absorption and emission data for $\mathbf{9}$ and $\mathbf{1 0 .}$

\begin{tabular}{|c|c|c|c|}
\hline 9 & $\lambda_{\mathrm{abs}} / \mathrm{nm}\left(\varepsilon / 10^{4} \mathrm{~mol}^{-1} \cdot \mathrm{dm}^{3} \cdot \mathrm{cm}^{-1}\right)$ & $\lambda_{\mathrm{em}} / \mathrm{nm}$ & $\Phi_{\mathrm{s}} 1$ \\
\hline $9 b$ & $258(3.1), 274(\mathrm{sh}), 297(2.6), 308(3.3), 331$ (sh) & 367 & 0.92 \\
\hline $9 c$ & 256 (3.5), 274 (sh), 297 (2.9), 308 (3.2), 326 (sh) & 368,378 & 0.88 \\
\hline $9 d$ & $258(4.6), 275(\mathrm{sh}), 298(4.0), 308(4.4), 326(\mathrm{sh})$ & 369,380 & 0.14 \\
\hline $9 e$ & 255 (sh), 275 (sh), $297(2.1), 309(2.4), 323$ (sh) & 371,379 & 0.77 \\
\hline $9 f$ & 250 (sh), 262 (sh), $297(3.1), 309$ (3.1), 323 (sh) & 370. 379 & 0.86 \\
\hline $9 g$ & 265(4.4), 275 (sh), 298 (sh), 309 (5.5), 326 (sh) & 370,380 & 1.00 \\
\hline $9 \mathrm{~h}$ & $252(\mathrm{sh}), 263$ (sh), $298(2.9), 309(3.1), 325$ (sh) & 373,380 & 0.69 \\
\hline $9 \mathbf{i}$ & 264 (sh), 299 (3.2), 309 (3.9), 323 (sh) & 386 & 0.78 \\
\hline $9 \mathbf{j}$ & 264 (sh), 298 (2.2), 309 (2.7), 324 (sh) & 391 & 0.37 \\
\hline 91 & $264(3.5), 298(3.0), 309(3.5), 326(\mathrm{sh})$ & 372,385 & 0.44 \\
\hline $9 m$ & 260 (sh), 278 (2.5), 297 (sh), 309 (1.6) & 370,380 & 0.64 \\
\hline $9 n$ & 264 (3.0), 275 (sh), $297(2.5), 309$ (3.0), 323 (sh) & 365 & 0.86 \\
\hline 9o & $265(3.9), 298(3.4), 310(4.0), 323(\mathrm{sh})$ & 367 & 0.91 \\
\hline
\end{tabular}

\section{Conclusions}

In summary, this work presented a simple method for the regioselective synthesis of 2,4-disubtituted fluorenols and the respective 9,9'-spirobifluorenes using a Ru-complex catalytic $[2+2+2]$-cyclotrimerization of diynes with terminal alkynes. Unlike the use of Rh-based catalytic systems that provide preferentially ortho-isomers, application of $\mathrm{Cp} * \mathrm{Ru}(\mathrm{cod}) \mathrm{Cl}$ as the catalyst provided predominantly the meta-isomers. The reaction proceeded under mild reaction conditions and a high functional group tolerance. The observed meta/ortho selectivity was usually $>9: 1$, and in some cases, only the meta-isomers were detected and isolated. The cyclotrimerizations yielded substituted fluorenols that were converted into the corresponding 9,9'-spirobifluorenes. A study of the photophysical properties of the corresponding 9,9'-spirobifluorenes showed that the presence of various substituents (based on aromatic systems) in positions 2 and 4 resulted in emission bands in the narrow region of $\lambda_{\mathrm{em}}=330-391 \mathrm{~nm}$ (in cyclohexane) and absolute quantum yields of emission $\Phi_{\mathrm{s}}=0.14-1.00$.

Supplementary Materials: Experimental details, diffraction analysis data, and copies of spectra are available online at http://www.mdpi.com/2073-4344/9/11/942/s1. 
Author Contributions: Synthesis and compound characterization I.C. (Ilaria Caivano), R.P.K., and F.S.; photochemical property measurement J.M. and D.N.; X-ray diffraction I.C. (Ivana Císařová); writing-original draft preparation and editing M.K.

Funding: This work was funded by Czech Science Foundation (grant No. 18-17823S). J. Mosinger would like to acknowledge the support from OP VVV project No. CZ.02.1.01/0.0/0.0/15_003/0000417 - CUCAM.

Conflicts of Interest: The authors declare no conflict of interest.

\section{References}

1. Shi, Y.; Gao, S. Recent Advances of Synthesis of Fluorenone and Fluorene Containing Natural Products. Tetrahedron 2016, 14, 1717-1735. [CrossRef]

2. Fleckenstein, C.A.; Plenio, H. 9-Fluorenylphosphines for the Pd-Catalyzed Sonogashira, Suzuki, and Buchwald-Hartwig Coupling Reactions in Organic Solvents and Water. Chem. Eur. J. 2007, 13, 2701-2716. [CrossRef] [PubMed]

3. King, D.S.; Fields, C.G.; Fields, G.B. A Cleavage Method Which Minimizes Side Reactions Following Fmoc Solid Phase Peptide Synthesis. Int. J. Pept. Protein Res. 1990, 36, 255-266. [CrossRef] [PubMed]

4. Hughes, G.; Bryce, M.R. Electron-transporting Materials for Organic Electroluminescent and Electrophosphorescent Devices. J. Mater. Chem. 2005, 15, 94-107. [CrossRef]

5. Saragi, T.P.I.; Spehr, T.; Siebert, A.; Fuhrmann-Lieker, T.; Salbeck, J. Spiro Compounds for Organic Optoelectronics. Chem. Rev. 2007, 107, 1011-1065. [CrossRef]

6. Wu, C.C.; Lin, Y.T.; Chiang, H.H.; Cho, T.Y.; Chen, C.W.; Wong, K.T.; Liao, Y.L.; Lee, G.H.; Peng, S.M. Highly bright blue organic light-emitting devices using spirobifluorene-cored conjugated compounds. Appl. Phys. Lett. 2002, 81, 577-581. [CrossRef]

7. Atul, G.; Sumit, C.; Manish, D.; Kumar, V.; Prakash, S.; Jena, B.; Verma, J.K.; Jain, M.; Anand, R.S.; Manoharan, S.S. Donor-Acceptor 9-Uncapped Fluorenes and Fluorenones as Stable Blue Light Emitters. Org. Lett. 2009, 6, 1289-1292.

8. Ingans, O.; Zhang, F.; Andersson, M.R. Alternating Polyfluorenes Collect Solar Light in Polymer Photovoltaics. Acc. Chem. Res. 2009, 42, 1731-1739. [CrossRef]

9. Etoria, H.; Jin, X.L.; Yasuda, T.; Mataka, S.; Tsutsui, T. Spirobifluorene Derivatives for Ultraviolet Organic Light-Emitting Diodes. Syn. Met. 2006, 156, 1090-1096. [CrossRef]

10. Lyu, Y.-Y.; Kwak, J.; Jeon, W.-S.; Byun, Y.; Lee, H.S.; Kim, D.; Lee, C.; Char, K. Highly Efficient Red Phosphorescent OLEDs based on Non-Conjugated Silicon-Cored Spirobifluorene Derivative Doped with Ir-Complexes. Adv. Funct. Mater. 2009, 19, 420-427. [CrossRef]

11. Moreau, F.; Audebrabd, N.; Poriel, C.; Moizan-Baslé, V.; Ouvry, J. A 9,9'-spirobifluorene Based Metal-Organic Framework: Synthesis, Structure Analysis and Gas Sorption Properties. J. Mater. Chem. 2011, 21, 18715-18722. [CrossRef]

12. Thiery, S.; Declairieux, C.; Tondelier, D.; Seo, G.; Geoffry, B.; Jeannin, O.; Metivier, R.; Rault-Berthelot, J.; Poriel, C. 2-Substituted vs. 4-substituted-9,9'-spirobifluorene host materials for green and blue phosphorescent OLEDs: A structure-Property for green and blue phosphorescent OLEDs: A structure-Property. Tetrahedron 2014, 70, 6337-6351.

13. Thiery, S.; Tondelier, D.; Declairieux, S.; Seo, G.; Geoffry, B.; Jeannin, O.; Metivier, R.; Rault-Berthelot, J.; Poriel, C. 9,9'-Spirobifluorene and 4-phenyl-9,9'-spirobifluorene: Pure hydrocarbon small molecules as hosts for efficient green and blue PhOLEDs. J. Mater. Chem. C 2014, 2, 4156-4166. [CrossRef]

14. Thiery, S.; Tondelier, D.; Declairieux, S.; Geoffry, B.; Jeannin, O.; Metivier, R.; Rault-Berthelot, J.; Poriel, C. 4-Pyridyl-9,9'-spirobifluorenes as Host Materials for Green and SkyBlue Phosphorescent OLEDs. J. Phys. Chem. 2015, 119, 5790-5805.

15. Poriel, C.; Rault-Berthelot, J. Structure-property relationship of 4-substitutedspirobifluorenes as hosts for phosphorescent organic light emitting diodes: An overview. J. Mater. Chem. C 2017, 5, 3869-3897. [CrossRef]

16. Sicard, L.; Quinton, C.; Peltier, J.-D.; Tondelier, D.; Geffroy, B.; Biapo, U.; Métivier, R.; Jeannin, O.; Rault-Berthelot, J.; Poriel, C. Spirobifluorene Regioisomerism: A Structure-Property Relationship Study. Chem. Eur. J. 2017, 23, 7719-7727. [CrossRef]

17. Clarkson, R.G.; Gomberg, M. Spirans with FourAromatic Radicals on the Spiro Carbon Atom. J. Am. Chem. Soc. 1930, 52, 2881-2891. [CrossRef] 
18. Kaiser, R.P.; Caivano, I.; Kotora, M. Transition-metal-catalyzed methods for synthesis of fluorenes. Tetrahedron report 1186. Tetrahedron 2019, 75, 2981-2992. [CrossRef]

19. Reppe, W.; Schlichting, O.; Klager, K.; Toepel, T. Cyclisierende Polymerisation von Acetylen I Über Cyclooctatetraen. Liebigs Ann. Chem. 1948, 560, 1-92. [CrossRef]

20. Reppe, W.; Schweckendiek, W. Cyclisierende Polymerisation von Acetylen. III Benzol, Benzolderivate und hydroaromatische Verbindungen. Liebigs Ann. Chem. 1948, 560, 104-116.

21. Kaiser, R.P.; Hessler, F.; Mosinger, J.; Císařová, I.; Kotora, M. A [2+2+2]Cyclotrimerization Approach to Selectively Substituted Fluorenes and Fluorenols, and Their Conversion to 9,9'-Spirobifluorenes. Chem. Eur. J. 2015, 21, 13577-13582. [CrossRef] [PubMed]

22. Kaiser, R.P.; Mosinger, J.; Císařová, I.; Kotora, M. Synthesis of selectively 4-substituted 9,9'-spirobifluorenes and modulation of their photophysical properties. Org. Biomol. Chem. 2017, 15, 6913-6920. [CrossRef] [PubMed]

23. Broere, D.L.J.; Ruijter, E. Transition-Metal-Catalyzed [2+2+2]Cyclo(co)trimerizations. Synthesis 2012, 44, 2639-2672.

24. Hilt, G.; Hess, W.; Vogler, T.; Hengst, C. Ligand and Solvent Effects on Cobalt(I)-Catalysed Reactions: Alkyne Dimerisation Versus [2+2+2]Cyclotrimerisation Versus Diels-Alder Reaction Versus [4+2+2]cycloaddition. J. Organomet. Chem. 2005, 690, 5170-5181. [CrossRef]

25. Hilt, G.; Hengst, C.; Hess, W. Solvent-Dependent Regiochemical Cyclotrimerisation of Phenylacetylene with Cobalt Catalysts Containing Disulfide Ligands: A Case Study. Eur. J. Org. Chem. 2008, 13, 2293-2297. [CrossRef]

26. Komine, Y.; Miyauchi, Y.; Kobayashi, M.; Tanaka, K. Synthesis of Tri- and Diaryloxybenzenes by Rhodium-Catalyzed Complete Intermolecular [2+2+2]Cycloaddition of Aryl Ethynyl Ethers. Synlett 2010, 20, 3092-3098. [CrossRef]

27. Komine, Y.; Kamisawa, A.; Tanaka, K. Flexible Synthesis of Fused Benzofuran Derivatives by Rhodium-Catalyzed [2+2+2]Cycloaddition with Phenol-Linked 1,6-Diynes. Org. Lett. 2009, 11, 2361-2364. [CrossRef]

28. Tanaka, K.; Sawada, Y.; Aida, Y.; Thammathevo, M.; Tanaka, R.; Sagae, H.; Otake, Y. Rhodium-catalyzed Convenient Synthesis of Functionalized Tetrahydronaphthalenes. Tetrahedron 2010, 66, 1563-1569. [CrossRef]

29. Nishigaki, S.; Shivata, Y.; Tanaka, K. Rhodium-Catalyzed Chemo- and Regioselective Intermolecular Cross-Cyclotrimerization of Nonactivated Terminal and Internal Alkynes. J. Org. Chem. 2017, 82, 11117-11125. [CrossRef]

30. Fabbian, M.; Marsich, N.; Farnetti, E. Organoiridium compounds with bidentate phosphines as highly regioselective catalysts for alkynes cyclotrimerization. Inorg. Chim. Acta 2004, 357, 2881-2888. [CrossRef]

31. Takeuchi, R.; Tanaka, S.; Nakaya, Y. Iridium Complex-catalyzed [2+2+2]Cycloaddition of $\alpha, \omega$-Diynes with Monoalkynes: A New and Efficient Catalyst for Cyclotrimerization of Alkynes. Tetrahedron Lett. 2001, 42, 2991-2994. [CrossRef]

32. Kezuka, S.; Tanaka, S.; Ohe, T.; Nakaya, Y.; Takeuchi, R. Iridium Complex-Catalyzed [2+2+2]Cycloaddition of $\alpha, \omega$-Diynes with Monoynes and Monoene. J. Org. Chem. 2006, 71, 543-552. [CrossRef] [PubMed]

33. Hashimoto, T.; Okabe, A.; Mizuno, T.; Izawa, M.; Takeuchi, R. Iridium-catalyzed [2+2+2] cycloaddition of $\alpha, \omega$-diynes with alkynyl ketones and alkynyl esters. Tetrahedron 2014, 70, 8681-8689. [CrossRef]

34. Matoušová, E.; Gyepes, R.; Císařová, I.; Kotora, M. [2+2+2]Cyclotrimerization of 1-Cyclopropyl-1,6-diynes with Alkynes: Formation of Cyclopropylarenes. Adv. Synth. Catal. 2016, 358, 254-267. [CrossRef]

35. Van Leeuwen, P.W.N.M.; Kamer, P.C.J.; Reek, J.N.H.; Dierkes, P. Ligand Bite Angle Effects in Metal-catalyzed C-C Bond Formation. Chem. Rev. 2000, 100, 2741-2769. [CrossRef]

36. Birkholz (née Gensow), M.-N.; Freixa, Z.; van Leeuwen, P.W.N.M. Bite angle effects of diphosphines in C-C and C-X bond forming cross coupling reactions. Chem. Soc. Rev. 2009, 38, 1099-1118. [CrossRef]

37. Lee, T.-J.; Lee, D.H.; Kim, B.; Oh, H.S.; Kang, H.-R. Organic Electroluminiscent Device. WO 2018/182221 Al, 4 October 2018.

38. Yamamoto, Y.; Kinpara, K.; Saigoku, T.; Nishiyama, H.; Itoh, K. Synthesis of Benzo-fused Lactams and Lactonesvia Ru(ii)-Catalyzed Cycloaddition of Amide- and Ester-tethered $\alpha, \omega$-Diynes with Terminal Alkynes: Electronic Directing Effect of Internal Conjugated Carbonyl Group. Org. Biomol. Chem. 2004, 2, 1287-1294. [CrossRef] 
39. Jiang, Z.; Yao, H.; Zhang, Z.; Yang, C.; Liu, Z.; Tao, Y.; Qin, J.; Ma, D. Novel Oligo-9,9'-spirobifluorenes through ortho-Linkage as Full Hydrocarbon Host for Highly Efficient Phosphorescent OLEDs. Org. Lett. 2009, 11, 2607-2610. [CrossRef]

40. Fan, C.; Chen, Y.; Gan, P.; Yang, C.; Zhong, C.; Qin, J.; Ma, D. Tri-, Tetra- and Pentamers of 9,9'-Spirobifluorenes through Full ortho-Linkage: High Triplet-Energy Pure Hydrocarbon Host for Blue Phosphorescent Emitter. Org. Lett. 2010, 12, 5648-5651. [CrossRef]

41. Cui, L.-S.; Xie, Y.-M.; Wang, Y.-K.; Zhong, C.; Deng, Y.-L.; Liu, X.-Y.; Jiang, Z.-Q.; Liao, L.-S. Pure Hydrocarbon Hosts for $\approx 100 \%$ Exciton Harvesting in Both Phosphorescent and Fluorescent Light-Emitting Devices. Adv. Mater. 2015, 27, 4213-4217. [CrossRef]

42. Jang, S.E.; Joo, C.W.; Jeon, S.O.; Yook, K.S.; Lee, J.Y. Pure Hydrocarbon Hosts for $\approx 100 \%$ Exciton Harvesting in Both Phosphorescent and Fluorescent. The Relationship between the Substitution Position of the Diphenylphosphine oxide on the Spirobifluorene and Device Performances of Blue Phosphorescent Organic Light-emitting Diodes. Org. Electron. 2010, 11, 1059-1065.

43. Dong, S.-C.; Gao, C.-H.; Yuan, X.D.; Cui, L.-S.; Jiang, Z.-Q.; Lee, S.-T.; Liao, L.S. Novel Dibenzothiophene Based Host Materials Incorporating Spirobifluorene for High-efficiency White Phosphorescent Organic Light-emitting Diodes. Org. Electron. 2013, 14, 902-908. [CrossRef]

44. Dong, S.-C.; Gao, C.-H.; Zhang, Z.-H.; Jiang, Z.-Q.; Lee, S.-T.; Liao, L.-S. New Dibenzofuran/spirobifluorene Hybrids as Thermally Stable Host Materials for Efficient Phosphorescent Organic Light-emitting Diodes with Low Efficiency Roll-off. Phys. Chem. Chem. Phys. 2012, 14, 14224-14228. [CrossRef] [PubMed]

45. Quinton, C.; Thiery, S.; Jeannin, O.; Tondelier, D.; Geffroy, B.; Jacques, E.; Rault-Berthelot, J.; Poriel, C. Electron-Rich 4-Substituted Spirobifluorenes: Toward a New Family of High Triplet Energy Host Materials for High-Efficiency Green and Sky Blue Phosphorescent OLEDs. ACS Appl. Mater. Interfaces 2017, 9, 6194-6206. [CrossRef] [PubMed]

(C) 2019 by the authors. Licensee MDPI, Basel, Switzerland. This article is an open access article distributed under the terms and conditions of the Creative Commons Attribution (CC BY) license (http://creativecommons.org/licenses/by/4.0/). 